\title{
Itch and Cough - Similar Role of Sensory Nerves in Their Pathogenesis
}

\section{Tatiana PECOVA ${ }^{1}$, Ivan KOCAN ${ }^{2}$, Robert VYSEHRADSKY ${ }^{2}$, Renata PECOVA $^{3}$}

${ }^{1}$ Clinic of Dermatovenerology, Jessenius Faculty of Medicine in Martin, Comenius University in Bratislava, University Hospital in Martin, Martin, Slovak Republic, ${ }^{2}$ Clinic of Pneumology and Phthisiology, Jessenius Faculty of Medicine in Martin, Comenius University in Bratislava, University Hospital in Martin, Martin, Slovak Republic, ${ }^{3}$ Department of Pathological Physiology, Jessenius Faculty of Medicine in Martin, Comenius University in Bratislava, Martin, Slovak Republic

Received October 7, 2019

Accepted November 25, 2019

\section{Summary}

Itch is the most common chief complaint in patients visiting dermatology clinics and is analogous to cough and also sneeze of the lower and upper respiratory tract, all three of which are host actions trying to clear noxious stimuli. The pathomechanisms of these symptoms are not completely determined. The itch can originate from a variety of etiologies. Itch originates following the activation of peripheral sensory nerve endings following damage or exposure to inflammatory mediators. More than one sensory nerve subtype is thought to subserve pruriceptive itch which includes both unmyelinated C-fibers and thinly myelinated $A \delta$ nerve fibers. There are a lot of mediators capable of stimulating these afferent nerves leading to itch. Cough and itch pathways are mediated by small-diameter sensory fibers. These cough and itch sensory fibers release neuropeptides upon activation, which leads to inflammation of the nerves. The inflammation is involved in the development of chronic conditions of itch and cough. The aim of this review is to point out the role of sensory nerves in the pathogenesis of cough and itching. The common aspects of itch and cough could lead to new thoughts and perspectives in both fields.

\section{Key words}

Cough $\bullet$ Itch $\bullet$ Sensory fibers $\bullet$ C-fibers $\bullet$ A-fibers

\section{Corresponding author}

R. Péčová, Department of Pathological Physiology, Jessenius Faculty of Medicine in Martin, Comenius University Bratislava, Malá Hora 4C, 03601 Martin, Slovak Republic. E-mail: renata.pecova@uniba.sk

\section{Introduction}

Itch is a common sensation that drives an intense urge to scratch. Itch and scratching have persisted in humans and many other species, suggesting that they play an important role in survival (Sanders et al. 2019). Mammals have evolved neurophysiologic reflexes such as coughing and scratching to expel invading pathogens and noxious environmental stimuli. It is well established that these responses are also associated with chronic inflammatory diseases such as asthma and atopic dermatitis. However, the mechanisms by which inflammatory pathways promote sensations such as itch remain poorly understood (Oetjen et al. 2017). Histological analyses of tissues from atopic patients have revealed striking increases in innervation at sites of inflammation. This was identified early in the skin of patients with atopic dermatitis (Tobin et al. 1992) but has now been shown in other tissues such as the lung in asthma (Myers et al. 2002). This increase in sensory neuron density is believed to contribute to atopic hypersensitivity, and worsening barrier damage, potentially caused by chronic itching or coughing, has been shown to increase tissue innervation (Valtcheva et al. 2015).

\section{Sensory fibers pathways in itching and cough}

The sensory nervous system is tasked with 
relaying peripheral signals to the brain. It broadly includes the somatosensory nervous system which transmits conscious perception of multiple sensations such as itch, nociception, mechanoreception, and proprioception through unique families of sensory neurons as well as the autonomic nervous system which transmits visceral sensations and homeostatic signals (Bautista et al. 2014). To accomplish this, sensory neurons send projections from their cell bodies, located in discrete ganglia throughout the body, toward both the central nervous system (CNS) and barrier surfaces. For example, conscious sensations from the skin of the body are carried along projecting axons of sensory nerves to the dorsal root ganglia (DRG) where their signals are then transmitted to the spinal cord and brain. Initiation of these signals begins in peripheral terminals of sensory neurons with localized depolarization due to activation of neuronal receptors and membrane ion channels. Given a sufficient stimulus, local activation can lead to increased action potential firing of projecting sensory neurons which results in CNS transmission. Thus, determining the function of specific receptors and channels expressed by sensory neurons at barrier surfaces is critical to understanding the mechanisms underlying dysregulated sensory responses (Oetjen and Kim 2018). Sensory neurons that play a role in itch or cough can be classified into two distinct fibers, the thinly myelinated A $\delta$-fiber and the unmyelinated C-fiber (LaVinka and Dong 2013).

\section{A-fibers in itching and cough}

Itch

Pruriceptive itch originates when specific sensory nerve terminals, generally located in the skin, are activated. Pruriceptive itch can also original from certain mucosal surfaces; however, a majority of research on itch has focused on sensory nerve fibers from the skin (Wallengren 2005). The excitation of sensory nerve fibers in the skin leading to pruriceptive itch occurs upon exposure of certain sensory nerve terminals to a pruritic substance and frequently follows skin damage or inflammation. Sensory nerve fibers in the skin originate from the distal processes of primary afferent dorsal root ganglion neurons. Sensory nerve fibers in the skin are broadly classified according to their condition of velocity and the sensory modalities that excite them. Fast conducting myelinated nerve fibers $(A \beta)$ respond to nonnoxious mechanical stimulation of the skin, while slow conducting myelinated $(\mathrm{A} \delta)$ and unmyelinated $(\mathrm{C})$ nerves fibers respond to noxious stimulation and temperature changes of the skin (McGlone and Reilly 2010). It has been shown in studies involving the known pruritogen cowhage (Mucuna pruriens), that mechanosensitive A $\delta$-fibers play a role in itch. Cowhage causes intense itching when injected into the skin (Shelley and Arthur 1957). In monkeys, cowhage activates mechanosensitive A-fibers while some mechanoinsensitive A-fibers are activated by another pruritogen, histamine (Ringkamp et al. 2011, LaVinka and Dong 2013).

\section{Cough}

$\mathrm{A} \delta$-fibers fibers are unique in their lack of response to tissue distension, airway smooth muscle contraction and inflammatory mediators. They are, however, exquisitely sensitive to punctate mechanical stimulation (touch) of the epithelium. These terminals are also sensitive to acid, but only when there is a rapid drop in $\mathrm{pH}$ (Kollarik and Undem 2002). The unique structures of these terminals have been described in guinea pig trachea, and nerves with similar structures have recently been described in human bronchi (Mazzone et al. 2009, West et al. 2015). Physiological studies have revealed that stimulation of these fibers cause a strong cough response, even when an animal is anaesthetized (Canning et al. 2004). It stands to reason that these bona fide "cough receptors" provide a selective advantage by reducing the potentially lethal complications of aspiration (Mazzone and Undem 2016).

A $\beta$-fibers (rapidly adapting receptors - RARs, slowly adapting receptors - SARs, stretch receptors). The vagal afferent fibers terminating in the respiratory tract that conduct action potentials in the $A \beta$ range are by in large sensitive to the lung distention evoked by inspiration (Lee and Yu 2014, Sant'Ambrogio 1987). A subset is also sensitive to the mechanical forces caused by lung deflation (Liu and Yu 2013).

The role of myelinated fibers in cough is much more defined and explored when compared to myelinated fibers' role in itch. What is interesting in both is that these myelinated fibers are not solely responsible for the genesis of itch or cough. In both itch and cough, C-fibers play a role in setting the threshold, controlling the sensitivity of the system (LaVinka and Dong 2013).

\section{C-fibers in itching and cough}

Itch is primarily mediated by slower conducting C-fibers innervating the dorsal horn of the spinal cord. 
Early itch studies used spicules of cowhage to show that the strongest itch is felt in the dermo-epidermal juncture area, the area where unmyelinated sensory fibers innervate (LaVinka and Dong 2013). Two itch-sensitive pathways exist: a histamine-stimulated pathway that uses mechanically insensitive $\mathrm{C}$-fibers, and a cowhagestimulated pathway primarily involving polymodal Cfibers. In typical circumstances, pruritogens stimulate skin receptors and activate the peripheral pathway of itch. This provokes a signalling cascade and action potentials in at least two types of C-fibers. These nerve fibers conduct the action potential to the dorsal horn of the spinal cord. The itch pathways are stimulated by histamine and cowhage skin receptors in the epidermis and dermis, respectively. Impulses are transmitted primarily via mechanically insensitive C-fibers and polymodal C-fibers, respectively, to secondary neurons in the dorsal horn. One means of modulation by the pain pathway is through a Bhlbb5 interneuron (Dhand and Aminoff 2014).

\section{Cough}

In the respiratory tract, $\mathrm{C}$-fibers are often subclassified as pulmonary C-fibers or bronchial C-fibers, depending on whether the terminations receive blood supply from the pulmonary or bronchial circulation (Coleridge and Coleridge 1984). Operationally a C-fiber is considered to be a pulmonary $\mathrm{C}$-fiber if it responds to a chemical stimulant with short latency when delivered by right atrial injection to the pulmonary circulation. A Cfiber is termed "bronchial" if it is located in the large airways or if it responds with short latency to a chemical stimulant injected directly into the systemic circulation, i.e., into the bronchial artery. Pulmonary C-fibers are thought to terminate largely in the lung interstitium close to the pulmonary capillaries. For this reason, these fibers were referred to as juxtacapilliary receptors or J-receptors (Paintal 1969, Mazzone and Undem 2016).

Vagal C-fibers innervating the respiratory tract have been subclassified based on whether the cell body is situated in the jugular (neural crest-derived) or nodose (placodal-derived) ganglia (Undem et al. 2004). Extensive studies in mice and guinea pigs reveal the C-fiber nerve phenotype is distinct between nodose and jugular $\mathrm{C}$-fibers. The jugular C-fibers are more apt to contain sensory neuropeptides than nodose $\mathrm{C}$-fibers. The nodose $\mathrm{C}$-fibers can be stimulated by a wider range of chemical stimuli than jugular C-fibers (Nassenstein et al. 2010).

The majority of C-fibers terminating in the large extrapulmonary airways of guinea pigs are jugular $\mathrm{C}$ - fibers, with nodose C-fibers comprising only 10-20\% of tracheal C-fibers (Riccio et al. 1996). In contrast, similar numbers of nodose and jugular C-fibers terminate in the intrapulmonary tissues (Undem et al. 2004). Importantly, where it has been studied, the C-fiber phenotype of a nodose and jugular C-fiber remains constant regardless of where it terminates within the respiratory tract. Therefore, when describing phenotypic subsets of Cfibers, the embryonic history has advantages over the location of the terminations. That embryonic history is important is verified by the observation that the jugular C-fiber phenotype is similar to the C-fibers that arise from neurons within the dorsal root ganglia (like jugular neurons, they too are derived from the neural crest) (Surdenikova et al. 2012).

Nodose and jugular C-fibers respond to potentially damaging mechanical forces in a graded fashion. They also respond to inflammatory mediators and tissue acidification (Mazzone and Undem 2016).

Unmyelinated C-fiber afferents comprise the majority of afferent nerves innervating the airways (Coleridge and Coleridge 1984). Afferent C-fibers are distinguished from mechanically sensitive afferents by their conduction velocity and their direct responsiveness to a wide variety of chemical substances acting at both ligand-gated ion channels and $G$ protein-coupled receptors (Widdicombe 2001). The direct sensitivity of this class of afferents to chemical stimuli is inferred by the observation that chemical activation of $\mathrm{C}$-fiber endings in the airways is not inhibited by pretreatment with a bronchodilator. Furthermore, this is supported by expression studies in vagal ganglia preparations which show a wide variety of ion channels and receptors in C-fiber afferents and by the ability of ligands of these receptors to produce action potentials in patch recordings of acutely isolated vagal neurons in culture (Mazzone and Undem 2016). Indeed, bronchodilators such as prostaglandin $\mathrm{E}_{2}\left(\mathrm{PGE}_{2}\right)$ and epinephrine actually enhance afferent $\mathrm{C}$-fiber excitability rather than inhibit it (Lee and Pisarri 2001). C-fibre endings are polymodal, and thus can respond to both chemical and mechanical stimulation; their high threshold for mechanical activation means that $\mathrm{C}$-fibers generally don't fire action potentials throughout the respiratory cycle but rather are recruited in times of tissue injury/inflammation or in the presence of noxious chemicals. Indeed, in addition to the long list of chemicals that can activate $\mathrm{C}$-fibers, many inflammatory mediators can additionally sensitize C-fibers and lower their threshold for activation such that more physiological 
stimuli (e.g., bronchoconstriction) may activate C-fibers in the diseased airways (Mazzone and Undem 2016).

A subpopulation of C-fibers synthesize neuropeptides that are subsequently transported to their central and peripheral nerve terminals (Mazzone et al. 2009), and this has been exploited to describe the morphology of C-fibers in a variety of species, including rats and guinea pigs. Neuropeptide staining of large airway wholemount preparations or of tissue sections of the lung shows a vast plexus of fine varicose fibers innervating the airway epithelium and effector structures such as airway smooth muscle, glands, the vasculature, and autonomic ganglia within the airway wall. It is important to note that the expression of neuropeptides in C-fibers is both speciesdependent (for example, human vagal afferents contain fewer neuropeptides than do guinea pigs or rats) and dependent on the ganglionic origin of the $\mathrm{C}$-fiber (nodose C-fibers largely do not express substance P or CGRP), and as such, it is not clear if the described morphology is true of all C-fibers and in all species (Mazzone and Undem 2016).

The absence versus presence of neuropeptide expression in subsets of $\mathrm{C}$-fibers represents one example of heterogeneity among chemically sensitive afferent neurons. In dogs, airway C-fibers have been classified as "bronchial" or "pulmonary," a distinction based partly on anatomical termination sites and supported by differences in functional responsiveness to stimuli (Coleridge and Coleridge 1984). For example, bronchial C-fibers in dogs, but not pulmonary $\mathrm{C}$-fibers, are responsive to histamine. However, this is not true in guinea pigs, as histamine is without direct effect on any airway C-fibers (Coleridge $e t$ al. 1978). Nevertheless, C-fiber subtypes have been identified innervating the airways and lungs of mice, rats, and guinea pigs, distinguished based on their ganglionic origin, molecular phenotype, responsivity, and termination sites within the airways (Ricco et al. 1996, Mazzone and Undem 2016).

Knowing that itch and cough are mediated by similar sensory neurons, the specifics of activating these fibers can be examined and compared. Two types of receptors are activated on sensory fibers, ionotropic and metabotropic. In both of these categories, itch and cough work through the same receptors in multiple instances (LaVinka and Dong 2013).

\section{TRPV1 receptor}

The transient receptor potential, vanilloid 1
(TRPV1) receptor is a membrane-bound, ligand-gated channel. It is a six transmembrane spanning protein that undergoes a conformational change upon binding of a ligand, allowing cations into the nerve and resulting in activation of primary sensory neurons (Caterina et al. 1997).

Itch

The most famous TRPV1 ligand is capsaicin. If capsaicin is applied in a punctuate manner to the epidermis, it causes itch (Sikand et al. 2009). TRPV1 plays an important role in histamine-dependent itch (LaVinka and Dong 2013). TRPV1 is an important component in multiple itch pathways (Patel et al. 2011). TRPV1 expression is increased in itching skin lesions and its activation promotes itch by secreting soluble factors (Steinhoff et al. 2003).

\section{Cough}

Potential (TRP) family are a large family of ion channel proteins some of which are expressed on airway sensory nerve terminals (Bonvini and Belvisi 2017). TRPV1 is also thought to be a strong effector of the cough reflex in response to many different stimuli (Grace et al. 2012). TRPV1 is found in both vagal ganglia as well as throughout the airway (Watanabe et al. 2006). Airway mucosal biopsies from patients suffering from chronic cough showed a fivefold increase in TRPV1 expression (Groneberg et al. 2004). Capsaicin is a commonly used tussive agent and resiniferatoxin, a strong TRPV1 agonist, causes cough by direct activation of TRPV1 (Laude et al. 1993). $\mathrm{PGE}_{2}$ and bradykinin, which are known to cause cough, depolarize vagal sensory neurons through activation of TRPV1 (Grace et al. 2012). Citric acid evoked cough works through activation of TRPV1 and antagonizing the receptor with capsazepine reduces citric acid cough (Lalloo et al. 1995).

\section{TRPA1 receptor}

The Transient Receptor Potential Ankyrin 1 (TRPA1) channel, originally called ANKTM1 (Story et al. 2003), is an ion channel dominantly expressed in a subset of nociceptive somatosensory neurons where it acts as a polymodal sensor for diverse physical and chemical stimuli of extracellular or intracellular origin. There is progress in the identification of various signalling pathways involved in the sensitization of the TRP channels by pro-inflammatory agents (Kádková et al. 2017). 
Itch

In the skin, histamine-dependent mechanisms contribute to itch; however, several distinct histamineindependent itch mechanisms have also been described. One involves the Mas-gene-related $G$ protein-coupled receptor family, which includes MRGPRA3 and MRGPRC11 (LaMotte et al. 2014). Another mechanism involves the bile acid receptor TGR5, also known as GPR130 or GpBAR1 (Alemi et al. 2013). TRPA1 has been shown to be important to histamine-independent itch.

MRGPRA3 and MRGPRC11 are expressed by subsets of sensory DRG neurons innervating the skin. Activation of MRGPRA3 by the anti-malarial drug chloroquine, or MRGPRC11 activation by the endogenous pruritogen, bovine adrenal medulla 8-22 peptide (BAM822 ), induces itch. However, it remains unclear if both TGR5 and MRGPR mechanisms co-exist within the same DRG neuronal populations or whether they exist in, and therefore recruit distinct populations of DRG neurons (Castro et al. 2019).

Both TRPV1 and TRPA1 are co-expressed in a large subset of sensory nerves, where they integrate numerous noxious stimuli. It is now clear that the expression of both channels also extends far beyond the sensory nerves in the skin, occurring also in keratinocytes, mast cells, dendritic cells, and endothelial cells. In these non-neuronal cells, TRPV1 and TRPA1 also act as nociceptive sensors and potentiate the inflammatory process (Gouin et al. 2017).

While TRPV1 and TRPV4 are expressed both by sensory neurons and keratinocytes, it has recently been demonstrated that the specific and selective activation of TRPV1 on keratinocytes is sufficient to induce pain. Similarly, the targeted activation of keratinocyteexpressed TRPV4 elicits itch and the resulting scratching behavior (Talagas and Misery 2019).

\section{Cough}

TRPA1 is the only member of the Ankyrin family of TRP channels and was first discovered in cultured human lung fibroblasts (Jaquemar et al. 1999) but is now known to be widely expressed in sensory nociceptive neurons in the vagal, jugular and nodose ganglia (Story et al. 2003). However, unlike TRPV1, TRPA1 only seems to activate $\mathrm{C}$-fibers and interestingly single-cell PCR experiments identified that although they are often coexpressed in neurons within the jugular and nodose ganglia they are also found separately (Wortley et al. 2016). It is a polymodal ion channel shown to be a sensor of noxious cold (Story et al. 2003). TRPA1 channels are activated by a range of natural products such as allyl isothiocyanate, allicin and cannabinol, found in mustard oil, garlic and cannabis and by environmental irritants (Bonvini and Belvisi 2017). TRPA1 is also the molecular target for reactive and electrophilic by-products of oxidative stress. This also includes electrophiles such as hypochlorite and hydrogen peroxide (Taylor-Clark 2016). TRPA1 can also be indirectly activated by the inflammatory mediators $\mathrm{PGE}_{2}$ and bradykinin (Grace et al. 2012). In the airways, TRPA1 is highly expressed in neuronal tissue including nasal trigeminals, vagal airway neurons and spinal DRGs (Nassenstein et al. 2008, Wortley et al. 2016), and is predominantly expressed on $\mathrm{C}$ fibers (Robinson et al. 2018). Activation of TRPA1 causes activation of vagal bronchopulmonary $\mathrm{C}$ fibers (Nassenstein et al. 2008) and causes cough in both animals and man (Birrell et al. 2009). Unlike TRPV1, TRPA1 has only been shown to activate $\mathrm{C}$ fibers and not the more mechanically sensitive A $\delta$ fibers (Robinson et al. 2018).

The fact placebo and active had virtually identical effects on the cough counting speak strongly to the idea that blocking TRPA1 in the periphery, and indeed centrally may not have any effect on clinically important endpoints. Similarly, the failure of TRPV1 antagonists to make it to the clinic having shown a high degree of target engagement also suggests that peripheral sensitization is at best a minor feature of cough hypersensitivity syndrome. The recent success in multiple clinical studies of the ATP P2X3 receptor blocker AF219 (Abdulqawi et al. 2015) demonstrated that hypersensitization upstream of the vagal nerve terminals underlies the mechanism for cough hypersensitivity syndrome. TRPA1 antagonists may have a role in other disease areas but the current evidence suggests that we are unlikely to fundamentally interfere with the mechanism of cough hypersensitivity through peripheral receptor blockade (Morice 2017).

\section{Inflammatory mediators}

Activation of TRP channels leads to release of inflammatory neuropeptides from C-fibers. These neuropeptides include the tachykinins (Substance $\mathrm{P}$, neurokinin A, neurokinin B) and calcitonin gene-related peptide (CGRP) (Holzer 1998). Other inflammatory chemicals, such as bradykinin, may also be released. Neurogenic inflammation has been shown to play roles in both chronic itch and chronic cough (LaVinka and Dong 2013). 


\section{Substance P (SP)}

Itch

SP and neurokinin 1 receptor (NK1R) play an important role in itch signalling. This is supported by a large and growing body of evidence demonstrating that (i) NK1R is broadly expressed in multiple cell types in the skin, such as keratinocytes and mast cells, as well as the CNS; (ii) in many pruritic dermatological conditions, based on immunohistochemical studies, overexpression of NK1R is seen in the epidermis and increased numbers of SP-expressing nerve fibers and inflammatory cells are found in the skin; (iii) SP binding to NK1R-bearing neurons in the dorsal horn of the spine is a key relay point in itch signalling; and (iv) the blocking of NK1R via the use of NK1R antagonist interrupts transmission of the itch signal. SP and NK1R are overexpressed across multiple chronic itch-inducing conditions and that NK1R antagonism disrupts itch signalling and reduces itch provide a rationale for targeting this pathway as a potential treatment of chronic pruritus across multiple diseases (Ständer and Yosipovitch 2019).

\section{Cough}

Substance P and NK1R are implicated in chronic refractory cough pathophysiology. The efficacy and safety of orvepitant, a brain-penetrant NK1R antagonist, in an open-label study in patients with chronic refractory cough were established. Orvepitant resulted in a significant and sustained improvement in objective cough frequency, severity visual analogue scale (VAS), and quality of life; appeared safe, and merits further clinical investigation (Smith et al. 2019).

\section{Bradykinin}

Itch

In humans, the subjective response to intradermal injection of bradykinin is intense burning pain. Bradykinin injection also led to mild to moderate itch in about $60 \%$ of participants, but the itching was only noticed after cessation of the burning pain. The preference for pain over itch may change in atopic dermatitis where administration of bradykinin in lesional skin causes less pain and a robust itch sensation (Potenzieri and Undem 2012). Itch evoked by bradykinin is histamine-independent (Hosogi et al. 2006). Both kinin receptors, B1 and B2, are shown to contribute to itch (LaVinka and Dong 2013).
Cough

The mechanism of angiotensin-converting enzyme (ACE) inhibitor-induced cough remains unclear. Possible protussive mediators include bradykinin and substance $\mathrm{P}$, which are degraded by ACE and therefore accumulate in the upper airway or lung when the enzyme is inhibited; and prostaglandins, the production of which may be stimulated by bradykinin. Bradykinin-induced sensitization of airway sensory nerves has been proposed as a potential mechanism of ACE inhibitor-induced cough (Fox et al. 1996). Some evidence has suggested that the therapeutic effect of ACE inhibitors may involve the activation of bradykinin receptors (Ignjatovic et al. 2002), and that bradykinin receptor gene polymorphism is associated with the cough that is related to ACE inhibitors (Mukae et al. 2000). A dry, persistent cough is a welldescribed class effect of the angiotensin-converting enzyme (ACE) inhibitor medications (Dicpinigaitis 2006). Bradykinin's tussive effects are tied to the activation of TRPV1 and TRPA1 (LaVinka and Dong 2013).

\section{Histamine}

Itch

Histamine is one of the best-characterized pruritogens in humans. It is known to play a role in pruritus associated with urticaria as well as ocular and nasal allergic reactions. Histamine mediates its effect via four receptors. Antihistamines that block the activation of the histamine $\mathrm{H}_{1}$ receptor, $\mathrm{H}_{1} \mathrm{R}$, have been shown to be effective therapeutics for the treatment of pruritus associated with urticaria, allergic rhinitis, and allergic conjunctivitis. However, their efficacy in other pruritic diseases such as atopic dermatitis and psoriasis is limited. The other histamine receptors may also play a role in pruritus, with the exception of the histamine $\mathrm{H}_{2}$ receptor, $\mathrm{H}_{2} \mathrm{R}$. Preclinical evidence indicates that local antagonism of the histamine $\mathrm{H}_{3}$ receptor, $\mathrm{H}_{3} \mathrm{R}$, can induce scratching perhaps via blocking inhibitory neuronal signals. The histamine $\mathrm{H}_{4}$ receptor, $\mathrm{H}_{4} \mathrm{R}$, has received a significant amount of attention as to its role in mediating pruritic signals. Indeed, it has now been shown that a selective $\mathrm{H}_{4} \mathrm{R}$ antagonist can inhibit histamine-induced itch in humans. This clinical result, in conjunction with efficacy in various preclinical pruritus models, points to the therapeutic potential of $\mathrm{H}_{4} \mathrm{R}$ antagonists for the treatment of pruritus not controlled by antihistamines that target the $\mathrm{H}_{1} \mathrm{R}$ (Thurmond et al. 2015). 
Cough

The peripheral sensory and autonomic nervous system densely innervates mucosal barrier tissues including the skin, respiratory tract and gastrointestinal tract that are exposed to allergens. It is increasingly clear that neurons actively communicate with and regulate the function of mast cells, dendritic cells, eosinophils, $\mathrm{T}_{\mathrm{h}} 2$ cells and type 2 innate lymphoid cells in allergic inflammation. Several mechanisms of cross-talk between the two systems have been uncovered, with potential anatomical specificity. Immune cells release inflammatory mediators including histamine, cytokines or neurotrophins that directly activate sensory neurons to mediate itch in the skin, cough/sneezing and bronchoconstriction in the respiratory tract (Voisin et al. 2017). Causing increased cough sensitivity can lead to chronic cough and chronic cough sufferers do have elevated levels of histamine in their sputum and lungs (McGarvey et al. 1999, Birring et al. 2004).

\section{Serotonin}

Itch

5-HT (5-hydroxytryptamine, serotonin) is another endogenous biogenic amine that has been shown to evoke itch in humans (Potenzieri and Undem 2012). Consistent with this, 5-HT stimulates action potential discharge in a subset of human cutaneous C-fibers (Schmelz et al. 2003). The itch sensation evoked by 5-HT was weaker than the sensation of itch evoked by histamine (Schmelz et al. 2003, Hosogi et al. 2006). Although serotonin is a relatively weak pruritogen in normal nonlesioned skin, it should be kept in mind that it is a much stronger pruritogen when administered to lesioned skin from patients with atopic dermatitis (Hosogi et al. 2006). 5-HT also evokes scratching behavior in experimental animals and in rats, the scratching behavior to 5-HT is associated with activation of C-fibers, but not faster conducting myelinated nerve fibers (Hachisuka et al. 2010). Based on studies with selective 5-HT receptor subtype agonists and antagonists it appears that in mice the 5-HT2 receptor subtype is responsible for 5-HT-induced itch (Yamaguchi et al. 1999). 5-HT has also been proposed to be involved in the pathogenesis of pruritus in polycythaemia vera, a myeloproliferative neoplasm associated with intense itching (Diehn and Tefferi 2001). Selective serotonin reuptake inhibitors have displayed beneficial effects in palliative care patients with pruritus of different natures (Xander et al. 2013, Luo et al. 2015).
Cough

Serotonin stimulates respiratory reflexes (Coleridge et al. 1989). In dogs, phenylbiguanide, a 5-HT receptor agonist, activates bronchial $\mathrm{C}$-fibers (Coleridge and Coleridge 1977). Nodose ganglia C-fibers respond to serotonin. The guinea pig also shows activation of the 5-HT3 receptor on intrapulmonary nodose C-fibers (Lee $e t$ al. 2004). The jugular ganglion $C$ fibers in guinea pigs do not respond to 5-HT (Chuaychoo et al. 2005). However, 5-HT does stimulate jugular ganglion $\mathrm{C}$ fibers in mice, possibly through a metabotropic 5-HT receptor (Potenzieri et al. 2012). It is possible the metabotropic 5-HT2A receptor might be involved because in mouse tracheal preps, serotonin causes tracheal muscle contraction via the 5-HT2A receptor (Weigand et al. 2009, Campos-Bedolla et al. 2019). This contrasts with activation of the nodose $C$ fibers of mice, which is mediated by the ionotropic 5-HT3 receptor (Potenzieri et al. 2012, LaVinka and Dong 2013).

\section{Conclusion}

Itch is described as an irritating sensation that triggers a desire to scratch and the chronic itch is defined as pruritus lasting longer than 6 weeks. The pathophysiological mechanisms of chronic itch are poorly understood but likely involve sensitization of itchsignalling pathways. The sensory A $\delta$ - and, more importantly, C-fibers play a pivotal role in itch perception. Tied closely to activation of these sensory fibers is neurogenic inflammation, which involves the release of inflammatory agents like SP and bradykinin as well as products of mast cells, all which result in itch, flares, wheals, and can easily become chronic conditions. All of these individual factors also play roles in cough and the similarities between itch and cough in sensing irritants from the environment can be seen. Cough has an additional factor to incorporate though, movement. While the end result of the itch is scratching, the muscles and joints being used to scratch are not receiving signals directly from the itching skin. With cough, smooth muscle movement is incorporated into the actual cough reflex in order to move the irritant or blockage up the airway and out. It is this additional motility aspect that could result in more specialized involvement of myelinated fibers in cough, a specialization not needed in itch (LaVinka and Dong 
2013). Realizing the similarities between itch and cough can lead to new ideas and even perhaps, new ways to apply existing medications to new conditions. Clinically, anti-histamines are often prescribed and have been shown to help with itch and cough. However, by no means do anti-histamines help with all conditions. This indicates a real need to discover the histamine independent pathways involved. Progress has been made recently in histamine-independent itch research with the discovery of MRGPR genes. Future investigations into vagal neuroscience should also provide for novel therapeutic targets and strategies aimed at reducing the suffering of those inflicted with airway-related and also skin-related pathology.

\section{Ethical approval}

There are no unpublished experiments and data presented in this review article.

\section{Conflict of Interest}

There is no conflict of interest.

\section{Acknowledgements}

This work was supported by the project of Ministry of Health of the Slovak Republic 2018/12-UKMT-8.

\section{References}

ABDULQAWI R, DOCKRY R, HOLT K, LAYTON G, MCCARTHY BG, FORD AP, SMITH JA: P2X3 receptor antagonist (AF-219) in refractory chronic cough: a randomised, double-blind, placebo-controlled phase 2 study. Lancet 385: 1198-1205, 2015. https://doi.org/10.1016/S0140-6736(14)61255-1

ALEMI F, KWON E, POOLE DP, LIEU T, LYO V, CATTARUZZA F, CEVIKBAS F, STEINHOFF M, NASSINI R, MATERAZZI S, GUERRERO-ALBA R, VALDEZ-MORALES E, COTTRELL GS, SCHOONJANS K, GEPPETTI P, VANNER SJ, BUNNETT NW, CORVERA CU: The TGR5 receptor mediates bile acid-induced itch and analgesia. J Clin Invest 123: 1513-1530, 2013. https://doi.org/10.1172/JCI64551

BAUTISTA DM, WILSON SR, HOON MA: Why we scratch an itch: the molecules, cells and circuits of itch. Nat Neurosci 17: 175-82, 2014. https://doi.org/10.1038/nn.3619

BIRRELL MA, BELVISI MG, GRACE M, SADOFSKY L, FARUQI S, HELE DJ, MAHER SA, FREUND-MICHEL V, MORICE AH: TRPA1 agonists evoke coughing in guinea pig and human volunteers. Am J Respir Crit Care Med 180: 1042-1047, 2009. https://doi.org/10.1164/rccm.200905-0665OC

BIRRING SS, PARKER D, BRIGHTLING CE, BRADDING P, WARDLAW AJ, PAVORD ID: Induced sputum inflammatory mediator concentrations in chronic cough. Am J Respir Crit Care Med 169: 15-19, 2004. https://doi.org/10.1164/rccm.200308-10920C

BONVINI SJ, BELVISI MG: Cough and airway disease: The role of ion channels. Pulm Pharmacol Ther 47: 21-28, 2017. https://doi.org/10.1016/j.pupt.2017.06.009

CAMPOS-BEDOLLA P, DE-LA-CRUZ-NEGRETE R, VARGAS MH, TORREJÓN-GONZÁLEZ E, MEJÍAMENDOZA D, ISLAS-HERNÁNDEZ A, SEGURA-MEDINA P, CÓRDOBA-RODRÍGUEZ G, OROZCOSUÁREZ S, ARREOLA-RAMÍREZ JL: Allergic sensitization increases contractile responses to 5-HT in guinea pig aorta. Physiol Res 69: 191-197, 2020. https://doi.org/10.33549/physiolres.934128

CANNING BJ, MAZZONE SB, MEEKER SN, MORI N, REYNOLDS SM, UNDEM BJ: Identification of the tracheal and laryngeal afferent neurones mediating cough in anaesthetized guinea-pigs. J Physiol 557: 543-558, 2004. https://doi.org/10.1113/jphysiol.2003.057885

CASTRO J, HARRINGTON AM, LIEU T, GARCIA-CARABALLO S, MADDERN J, SCHOBER G, O'DONNELL T, GRUNDY L, LUMSDEN AL, MILLER PE, GHETTI A, STEINHOFF MS, POOLE DP, DONG X, CHANG L, BUNNETT NW, BRIERLEY SM: Activation of pruritogenic TGR5, MRGPRA3, and MRGPRC11 on coloninnervating afferents induces visceral hypersensitivity. JCI Insight 4 (20), 2019. pii: 131712. https://doi.org/10.1172/jci.insight.131712

CATERINA MJ, SCHUMACHER MA, TOMINAGA M, ROSEN TA, LEVINE JD, JULIUS D: The capsaicin receptor: a heat-activated ion channel in the pain pathway. Nature 389: 816-824, 1997. https://doi.org/10.1038/39807

CHUAYCHOO B, LEE MG, KOLLARIK M, UNDEM BJ: Effect of 5-hydroxytryptamine on vagal C-fiber subtypes in guinea pig lungs. Pulm Pharmacol Ther 18: 269-276, 2005. https://doi.org/10.1016/j.pupt.2004.12.010 
COLERIDGE HM, COLERIDGE JC: Impulse activity in afferent vagal C-fibres with endings in the intrapulmonary airways of dogs. Respir Physiol 29: 125-142, 1977. https://doi.org/10.1016/0034-5687(77)90086-X

COLERIDGE JC, COLERIDGE HM: Afferent vagal C fibre innervation of the lungs and airways and its functional significance. Rev Physiol Biochem Pharmacol 99: 1-110, 1984. https://doi.org/10.1007/BFb0027715

COLERIDGE HM, COLERIDGE JC, BAKER DG, GINZEL KH, MORRISON MA: Comparison of the effects of histamine and prostaglandin on afferent C-fiber endings and irritant receptors in the intrapulmonary airways. Adv Exp Med Biol 99: 291-305, 1978. https://doi.org/10.1007/978-1-4613-4009-6 32

COLERIDGE HM, COLERIDGE JC, SCHULTZ HD: Afferent pathways involved in reflex regulation of airway smooth muscle. Pharmacol Ther 42: 1-63, 1989. https://doi.org/10.1016/0163-7258(89)90021-1

DHAND A, AMINOFF MJ: The neurology of itch. Brain 137: 313-322, 2014. https://doi.org/10.1093/brain/awt158

DICPINIGAITIS PV: Angiotensin-converting enzyme inhibitor-induced cough: ACCP evidence-based clinical practice guidelines. Chest 129: 169S-173S, 2006. https://doi.org/10.1378/chest.129.1_suppl.169S

DIEHN F, TEFFERI A: Pruritus in polycythaemia vera: prevalence, laboratory correlates and management. Br J Haematol 115: 619-621, 2001. https://doi.org/10.1046/j.1365-2141.2001.03161.x

FOX AJ, LALLOO UG, BELVISI MG, BERNAREGGI M, CHUNG KF, BARNES PJ: Bradykinin-evoked sensitization of airway sensory nerves: a mechanism for ACE-inhibitor cough. Nat Med 2: 814-817, 1996. https://doi.org/10.1038/nm0796-814

GOUIN O, L'HERONDELLE K, LEBONVALLET N, LE GALL-IANOTTO C, SAKKA M, BUHÉ V, PLÉE-GAUTIER E, CARRÉ JL, LEFEUVRE L, MISERY L, LE GARREC R: TRPV1 and TRPA1 in cutaneous neurogenic and chronic inflammation: pro-inflammatory response induced by their activation and their sensitization. Protein Cell 8: 644-661, 2017. https://doi.org/10.1007/s13238-017-0395-5

GRACE M, BIRRELL MA, DUBUIS E, MAHER SA, BELVISI MG: Transient receptor potential channels mediate the tussive response to prostaglandin E2 and bradykinin. Thorax 67: 891-900, 2012. https://doi.org/10.1136/thoraxjnl-2011-201443

GRONEBERG DA, NIIMI A, DINH QT, COSIO B, HEW M, FISCHER A, CHUNG KF: Increased expression of transient receptor potential vanilloid-1 in airway nerves of chronic cough. Am J Respir Crit Care Med 170: 12761280, 2004. https://doi.org/10.1164/rccm.200402-1740C

HACHISUKA J, FURUE H, FURUE M, YOSHIMURA M: Responsiveness of C neurons in rat dorsal root ganglion to 5-hydroxytryptamine-induced pruritic stimuli in vivo. J Neurophysiol 104: 271-279, 2010. https://doi.org/10.1152/jn.00938.2009

HOLZER P: Neurogenic vasodilatation and plasma leakage in the skin. Gen Pharmacol 30: 5-11, 1998. https://doi.org/10.1016/S0306-3623(97)00078-5

HOSOGI M, SCHMELZ M, MIYACHI Y, IKOMA A: Bradykinin is a potent pruritogen in atopic dermatitis: a switch from pain to itch. Pain 126: 16-23, 2006. https://doi.org/10.1016/j.pain.2006.06.003

IGNJATOVIC T, TAN F, BROVKOVYCH V, SKIDGEL RA, ERDÖS EG: Novel mode of action of angiotensin I converting enzyme inhibitors: direct activation of bradykinin B1 receptor. J Biol Chem 277: 16847-16852, 2002. https://doi.org/10.1074/jbc.M200355200

JAQUEMAR D, SCHENKER T, TRUEB B: An ankyrin-like protein with transmembrane domains is specifically lost after oncogenic transformation of human fibroblasts. J Biol Chem 274: 7325-7333, 1999. https://doi.org/10.1074/jbc.274.11.7325

KÁDKOVÁ A, SYNYTSYA V, KRUSEK J, ZÍMOVÁ L, VLACHOVÁ V: Molecular basis of TRPA1 regulation in nociceptive neurons. A review. Physiol Res 66: 425-439, 2017. https://doi.org/10.33549/physiolres.933553

KOLLARIK M, UNDEM BJ: Mechanisms of acid-induced activation of airway afferent nerve fibres in guinea-pig. J Physiol 543: 591-600, 2002. https://doi.org/10.1113/jphysiol.2002.022848

LALLOO UG, FOX AJ, BELVISI MG, CHUNG KF, BARNES PJ: Capsazepine inhibits cough induced by capsaicin and citric acid but not by hypertonic saline in guinea pigs. J Appl Physiol 79: 1082-1087, 1995. https://doi.org/10.1152/jappl.1995.79.4.1082

LAMOTTE RH, DONG X, RINGKAMP M: Sensory neurons and circuits mediating itch. Nat Rev Neurosci 15: 19-31, 2014. https://doi.org/10.1038/nrn3641 
LAUDE EA, HIGGINS KS, MORICE AH: A comparative study of the effects of citric acid, capsaicin and resiniferatoxin on the cough challenge in guinea-pig and man. Pulm Pharmacol 6: 171-175, 1993. https://doi.org/10.1006/pulp.1993.1023

LAVINKA PC, DONG X: Molecular signaling and targets from itch: lessons for cough. Cough 9: 8, 2013. https://doi.org/10.1186/1745-9974-9-8

LEE LY, PISARRI TE: Afferent properties and reflex functions of bronchopulmonary C-fibers. Respir Physiol 125: $47-$ 65, 2001. https://doi.org/10.1016/S0034-5687(00)00204-8

LEE LY, YU J: Sensory nerves in lung and airways. Compr Physiol 4: 287-324, 2014. https://doi.org/10.1002/cphy.c130020

LEE MG, KOLLARIK M, CHUAYCHOO B, UNDEM BJ: Ionotropic and metabotropic receptor mediated airway sensory nerve activation. Pulm Pharmacol Ther 17: 355-360, 2004. https://doi.org/10.1016/j.pupt.2004.09.025

LIU J, YU J: Spectrum of myelinated pulmonary afferents (II). Am J Physiol Regul Integr Comp Physiol 305: 1059-1064, 2013. https://doi.org/10.1152/ajpregu.00125.2013

LUO J, FENG J, LIU S, WALTERS ET, HU H: Molecular and cellular mechanisms that initiate pain and itch. Cell Mol Life Sci 72: 3201-3223, 2015. https://doi.org/10.1007/s00018-015-1904-4

MAZZONE SB, UNDEM BJ: Vagal afferent innervation of the airways in health and disease. Physiol Rev 96: 975-1024, 2016. https://doi.org/10.1152/physrev.00039.2015

MAZZONE SB, REYNOLDS SM, MORI N, KOLLARIK M, FARMER DG, MYERS AC, CANNING BJ: Selective expression of a sodium pump isozyme by cough receptors and evidence for its essential role in regulating cough. J Neurosci 29: 13662-13671, 2009. https://doi.org/10.1523/JNEUROSCI.4354-08.2009

MCGARVEY LP, FORSYTHE P, HEANEY LG, MACMAHON J, ENNIS M: Bronchoalveolar lavage findings in patients with chronic nonproductive cough. Eur Respir J 13: 59-65, 1999. https://doi.org/10.1183/09031936.99.13105999

MCGLONE F, REILLY D: The cutaneous sensory system. Neurosci Biobehav Rev 34: 148-159, 2010. https://doi.org/10.1016/j.neubiorev.2009.08.004

MUKAE S, AOKI S, ITOH S, IWATA T, UEDA H, KATAGIRI T: Bradykinin B(2) receptor gene polymorphism is associated with angiotensin-converting enzyme inhibitor-related cough. Hypertension 36: 127-131, 2000. https://doi.org/10.1161/01.HYP.36.1.127

NASSENSTEIN C, KWONG K, TAYLOR-CLARK T, KOLLARIK M, MACGLASHAN DM, BRAUN A, UNDEM BJ: Expression and function of the ion channel TRPA1 in vagal afferent nerves innervating mouse lungs. J Physiol 586: 1595-1604, 2008. https://doi.org/10.1113/jphysiol.2007.148379

MORICE AH: TRPA1 receptors in chronic cough. Pulm Pharmacol Ther 47: 42-44, 2017. https://doi.org/10.1016/j.pupt.2017.05.004

MYERS AC, KAJEKAR R, UNDEM BJ: Allergic inflammation-induced neuropeptide production in rapidly adapting afferent nerves in guinea pig airways. Am J Physiol Lung Cell Mol Physiol 282: 775-781, 2002. https://doi.org/10.1152/ajplung.00353.2001

NASSENSTEIN C, KWONG K, TAYLOR-CLARK T, KOLLARIK M, MACGLASHAN DM, BRAUN A, UNDEM BJ: Expression and function of the ion channel TRPA1 in vagal afferent nerves innervating mouse lungs. J Physiol 586: 1595-1604, 2008. https://doi.org/10.1113/jphysiol.2007.148379

NASSENSTEIN C, TAYLOR-CLARK TE, MYERS AC, RU F, NANDIGAMA R, BETTNER W, UNDEM BJ: Phenotypic distinctions between neural crest and placodal derived vagal C-fibres in mouse lungs. J Physiol 588: 4769-4783, 2010. https://doi.org/10.1113/jphysiol.2010.195339

OETJEN LK, KIM BS: Interactions of the immune and sensory nervous systems in atopy. FEBS J 285: 3138-3151, 2018. https://doi.org/10.1111/febs.14465

OETJEN LK, MACK MR, FENG J, WHELAN TM, NIU H, GUO CJ, CHEN S, TRIER AM, XU AZ, TRIPATHI SV, LUO J, GAO X, YANG L, HAMILTON SL, WANG PL, BRESTOFF JR, COUNCIL ML, BRASINGTON R, SCHAFFER A, BROMBACHER F, HSIEH CS, GEREAU RW 4TH, MILLER MJ, CHEN ZF, HU H, DAVIDSON S, LIU Q, KIM BS: Sensory neurons co-opt classical immune signaling pathways to mediate chronic itch. Cell 171: 217-228, 2017. https://doi.org/10.1016/j.cell.2017.08.006 
PAINTAL AS: Mechanism of stimulation of type J pulmonary receptors. J Physiol 203: 511-532, 1969. https://doi.org/10.1113/jphysiol.1969.sp008877

PATEL KN, LIU Q, MEEKER S, UNDEM BJ, DONG X: Pirt, a TRPV1 modulator, is required for histamine-dependent and -independent itch. PLoS One 6: e20559, 2011. https://doi.org/10.1371/journal.pone.0020559

POTENZIERI C, UNDEM BJ: Basic mechanisms of itch. Clin Exp Allergy 42: 8-19, 2012. https://doi.org/10.1111/j.1365-2222.2011.03791.x

POTENZIERI C, MEEKER S, UNDEM BJ: Activation of mouse bronchopulmonary C-fibres by serotonin and allergenovalbumin challenge. J Physiol 590: 5449-5459, 2012. https://doi.org/10.1113/jphysiol.2012.237115

RICCIO MM, MYERS AC, UNDEM BJ: Immunomodulation of afferent neurons in guinea-pig isolated airway. J Physiol 491: 499-509, 1996. https://doi.org/10.1113/jphysiol.1996.sp021234

RICCO MM, KUMMER W, BIGLARI B, MYERS AC, UNDEM BJ: Interganglionic segregation of distinct vagal afferent fibre phenotypes in guinea-pig airways. J Physiol 496: 521-530, 1996. https://doi.org/10.1113/jphysiol.1996.sp021703

RINGKAMP M, SCHEPERS RJ, SHIMADA SG, JOHANEK LM, HARTKE TV, BORZAN J, SHIM B, LAMOTTE RH, MEYER RA: A role for nociceptive, myelinated nerve fibers in itch sensation. J Neurosci 31: 14841-14849, 2011. https://doi.org/10.1523/JNEUROSCI.3005-11.2011

ROBINSON RK, BIRRELL MA, ADCOCK JJ, WORTLEY MA, DUBUIS ED, CHEN S, MCGILVERY CM, HU S, SHAFFER MSP, BONVINI SJ, MAHER SA, MUDWAY IS, PORTER AE, CARLSTEN C, TETLEY TD, BELVISI MG: Mechanistic link between diesel exhaust particles and respiratory reflexes. J Allergy Clin Immunol 141: 1074-1084, 2018. https://doi.org/10.1016/j.jaci.2017.04.038

SANDERS KM, FAST K, YOSIPOVITCH G: Why we scratch: Function and dysfunction. Exp Dermatol 28: 1482-1484, 2019. https://doi.org/10.1111/exd.13977

SANT'AMBROGIO G: Nervous receptors of the tracheobronchial tree. Annu Rev Physiol 49: 611-627, 1987. https://doi.org/10.1146/annurev.ph.49.030187.003143

SCHELEGLE ES: Functional morphology and physiology of slowly adapting pulmonary stretch receptors. Anat Rec A Discov Mol Cell Evol Biol 270: 11-16, 2003. https://doi.org/10.1002/ar.a.10004

SHELLEY WB, ARTHUR RP: The neurohistology and neurophysiology of the itch sensation in man. AMA Arch Derm 76: 296-323, 1957. https://doi.org/10.1001/archderm.1957.01550210020004

SCHMELZ M, SCHMIDT R, BICKEL A, HANDWERKER HO, TOREBJORK HE: Specific C-receptors for itch in human skin. J Neurosci 17: 8003-8008, 1997. https://doi.org/10.1523/JNEUROSCI.17-20-08003.1997

SCHMELZ M, SCHMIDT R, WEIDNER C, HILLIGES M, TOREBJORK HE, HANDWERKER HO: Chemical response pattern of different classes of C-nociceptors to pruritogens and algogens. J Neurophysiol 89: 24412448, 2003. https://doi.org/10.1152/jn.01139.2002

SIKAND P, SHIMADA SG, GREEN BG, LAMOTTE RH: Similar itch and nociceptive sensations evoked by punctate cutaneous application of capsaicin, histamine and cowhage. Pain 144: 66-75, 2009. https://doi.org/10.1016/j.pain.2009.03.001

SMITH J, ALLMAN D, BADRI H, MILLER R, MORRIS J, SATIA I, WOOD A, TROWER M: The neurokinin-1 receptor antagonist orvepitant is a novel antitussive therapy for chronic refractory cough: results from a phase 2 pilot study (VOLCANO-1). Chest pii: $\quad$ S0012-3692(19)31451-5, 2019. https://doi.org/10.1016/j.chest.2019.08.001

STÄNDER S, YOSIPOVITCH G: Substance P and neurokinin 1 receptor are new targets for the treatment of chronic pruritus. Br J Dermatol [Epub ahead of print] https://doi.org/10.1111/bjd.18025

STEINHOFF M, NEISIUS U, IKOMA A, FARTASCH M, HEYER G, SKOV PS, LUGER TA, SCHMELZ M: Proteinase-activated receptor-2 mediates itch: a novel pathway for pruritus in human skin. J Neurosci 23: 61766180, 2003. https://doi.org/10.1523/JNEUROSCI.23-15-06176.2003

STORY GM, PEIER AM, REEVE AJ, EID SR, MOSBACHER J, HRICIK TR, EARLEY TJ, HERGARDEN AC, ANDERSSON DA, HWANG SW, MCINTYRE P, JEGLA T, BEVAN S, PATAPOUTIAN A: ANKTM1, a TRP-like channel expressed in nociceptive neurons, is activated by cold temperatures. Cell 112: 819-829, 2003. https://doi.org/10.1016/S0092-8674(03)00158-2 
SURDENIKOVA L, RU F, NASSENSTEIN C, TATAR M, KOLLARIK M: The neural crest- and placodes-derived afferent innervation of the mouse esophagus. Neurogastroenterol Motil 24: 517-525, 2012. https://doi.org/10.1111/nmo.12002

TALAGAS M, MISERY L: Role of keratinocytes in sensitive skin. Front Med (Lausanne) 6: $108,2019$. https://doi.org/10.3389/fmed.2019.00108

TAYLOR-CLARK TE: Role of reactive oxygen species and TRP channels in the cough reflex. Cell Calcium 60: $155-$ 162, 2016. https://doi.org/10.1016/j.ceca.2016.03.007

THURMOND RL, KAZEROUNI K, CHAPLAN SR, GREENSPAN AJ: Antihistamines and itch. Handb Exp Pharmacol 226: 257-290, 2015. https://doi.org/10.1007/978-3-662-44605-8_15

TOBIN D, NABARRO G, BAART DE LA FAILLE H, VAN VLOTEN WA, VAN DER PUTTE SC, SCHUURMAN HJ: Increased number of immunoreactive nerve fibers in atopic dermatitis. J Allergy Clin Immunol 90: 613-622, 1992. https://doi.org/10.1016/0091-6749(92)90134-N

VALTCHEVA MV, SAMINENI VK, GOLDEN JP, GEREAU RW 4TH, DAVIDSON S: Enhanced nonpeptidergic intraepidermal fiber density and an expanded subset of chloroquine-responsive trigeminal neurons in a mouse model of dry skin itch. J Pain 16: 346-356, 2015. https://doi.org/10.1016/j.jpain.2015.01.005

VOISIN T, BOUVIER A, CHIU IM: Neuro-immune interactions in allergic diseases: novel targets for therapeutics. Int Immunol 29: 247-261, 2017. https://doi.org/10.1093/intimm/dxx040

WALLENGREN J: Neuroanatomy and neurophysiology of itch. Dermatol Ther 18: 292-303, 2005. https://doi.org/10.1111/j.1529-8019.2005.00041.x

WATANABE N, HORIE S, MICHAEL GJ, KEIR S, SPINA D, PAGE CP, PRIESTLEY JV: Immunohistochemical colocalization of transient receptor potential vanilloid (TRPV)1 and sensory neuropeptides in the guinea-pig respiratory system. Neuroscience 141: 1533-1543, 2006. https://doi.org/10.1016/j.neuroscience.2006.04.073

WEIGAND LA, MYERS AC, MEEKER S, UNDEM BJ: Mast cell-cholinergic nerve interaction in mouse airways. J Physiol 587: 3355-3362, 2009. https://doi.org/10.1113/jphysiol.2009.173054

WEST PW, CANNING BJ, MERLO-PICH E, WOODCOCK AA, SMITH JA: Morphologic characterization of nerves in whole-mount airway biopsies. Am J Respir Crit Care Med 192: 30-39, 2015. https://doi.org/10.1164/rccm.201412-22930C

WIDDICOMBE J: Airway receptors. Respir Physiol 125: 3-15, 2001. https://doi.org/10.1016/S0034-5687(00)00201-2

WORTLEY MA, DUBUIS E, BONVINI SJ, WONG S, SHALA F, MAHER SA, ADCOCK JJ, SMITH JA, BIRRELL MA, BELVISI MG: Making sense of sensory nerves: An in vitro characterisation of gene expression profiles of airway-innervating guinea-pig airway neurons using single-cell analysis. Am J Respir Crit Care Med 193: A6002, 2016.

XANDER C, MEERPOHL JJ, GALANDI D, BUROH S, SCHWARZER G, ANTES G, BECKER G: Pharmacological interventions for pruritus in adult palliative care patients. Cochrane Database Syst Rev 6: CD008320, 2013. https://doi.org/10.1002/14651858.CD008320.pub2

YAMAGUCHI T, NAGASAWA T, SATOH M, KURAISHI Y: Itch-associated response induced by intradermal serotonin through 5-HT2 receptors in mice. Neurosci Res 35: 77-83, 1999. https://doi.org/10.1016/S0168$\underline{0102(99) 00070-X}$ 